\title{
Przychody pierwotne a nierówności dochodowe w krajach wschodzących
}

Olgierd Kotyło*

\section{Wprowadzenie}

W ostatnich dziesięcioleciach nierówności dochodowe wyraźnie wzrastały, co przyczyniło się do powrotu do głównego nurtu debaty ekonomicznej zagadnień związanych z podziałem dochodu. Koncepcje teoretyczne powstające w celu wyjaśnienia tego zjawiska odwoływały się przede wszystkim do zmian technologicznych, ewolucji instytucji rynku pracy oraz skutków globalizacji. (Kierzenkowski, Koske 2013, s. 6). W tej ostatniej grupie mieszczą się teorie odnoszące się do trzech różnych wymiarów zjawiska globalizacji: przepływów siły roboczej (migracje ekonomiczne), przepływów dóbr i usług (handel zagraniczny) oraz przepływów kapitału (zagraniczne inwestycje bezpośrednie oraz portfelowe).

Przepływy towarów oraz czynników produkcji związane z procesami globalizacyjnymi generują istotne międzynarodowe strumienie dochodów. Upraszczając - wspomniane przepływy można utożsamiać z transferem zysków z zagranicznych oddziałów krajowych przedsiębiorstw oraz transferem dochodów emigrantów do kraju pochodzenia (MFW 2014, s. 219-234). W bilansie płatniczym omawiane strumienie są rejestrowane na rachunku obrotów bieżących jako dochody pierwotne (Nakoneczna-Kisiel 2016, s. 113). Celem pracy jest zbadanie wpływu, jaki procesy globalizacyjne wywierają na nierówności dochodowe w kraju pochodzenia czynników produkcji poprzez kanał przychodów pierwotnych ${ }^{1}$. Postanowiono skoncentrować się na krajach wschodzących ${ }^{2}$, dotychczas rzadko uwzględnianych w badaniach nad omawianym zjawiskiem.

* Olgierd Kotyło - student, Szkoła Główna Handlowa w Warszawie, kierunek studiów: ekonomia, olgierd.kotylo@gmail.com.

${ }^{1} \mathrm{Z}$ ang. primary income receipts. W polskiej terminologii bilansu płatniczego pozycja ,przychody” w kategorii „dochody pierwotne” na rachunku obrotów bieżących (www.nbp.pl/home.aspx). W niniejszej pracy dla zwięzłości używa się pojęcia „przychody pierwotne”.

${ }^{2}$ Spotyka się różne definicje rynków wschodzących. Na potrzeby niniejszej pracy przyjęto klasyfikację zgodną z metodologią dostawcy indeksów giełdowych MSCI Inc. (www.msci.com/indexes). 
W pierwszej części artykułu przedstawiono wybrane koncepcje teoretyczne wiążące wzrost nierówności dochodowych z różnymi wymiarami zjawiska globalizacji. Kolejną część poświęcono omówieniu wyników dotychczasowych badań empirycznych obracających się wokół zależności pomiędzy przychodami pierwotnymi a nierównościami dochodowymi. W części trzeciej zaprezentowano własną analizę omawianej zależności przeprowadzoną za pomocą narzędzi kointegracji panelowej: kolejno omówiono wykorzystane dane, zastosowaną metodologię oraz uzyskane rezultaty. Część czwarta jest podsumowaniem przeprowadzonych rozważań. Artykuł zamyka aneks o charakterze statystycznym.

\section{Globalizacja a nierówności - zarys teorii}

Na zjawisko globalizacji składają się procesy związane z przepływami towarów, siły roboczej oraz kapitału. Handel zagraniczny, zgodnie z klasycznym podejściem opartym na teorii Heckshera - Ohlina i twierdzeniu Stolpera - Samuelsona, powinien skutkować specjalizacją poszczególnych krajów w produkcji dóbr wykorzystujących czynnik produkcji występujący we względnej obfitości (Budnikowski 2014, s. 9097). W efekcie w krajach rozwiniętych następowałby wzrost dochodów pracowników wysoko wykwalifikowanych (i wzrost nierówności dochodowych), a w krajach rozwijających się - wzrost dochodów pracowników nisko wykwalifikowanych (i spadek nierówności dochodowych). Podnosi się jednak, że przepływy handlowe pomiędzy krajami rozwiniętymi a rozwijającymi się w dobie dominacji handlu wewnątrzgałęziowego są zbyt małe, aby mogły wpłynąć znacząco na rozkład dochodów ludności (Kierzenkowski, Koske 2013, s. 9).

Teorie analizujące skutki dystrybucyjne przepływów siły roboczej koncentrują się na konsekwencjach imigracji dla kraju przyjmującego. Sugeruje się, że imigracja może przyczyniać się do wzrostu nierówności dochodowych w kraju przyjmującym, jeżeli struktura kwalifikacji migrantów odbiega od struktury kwalifikacji pracowników miejscowych, co prowadzi do zmiany płac względnych różnych grup pracowników (Card 2009, s. 18-19). Sumaryczna zależność pomiędzy emigracją a nierównościami dochodowymi w kraju pochodzenia migrantów nie została dotychczas szczegółowo opracowana. Badano natomiast - pozostające w bezpośrednim związku z tematem niniejszej pracy - skutki dystrybucyjne transferu dochodów emigrantów do kraju pochodzenia. Poza oddziaływaniem na dochody bieżące beneficjentów opisywane transfery w długim okresie mogą łagodzić niedoskonałości rynku kapitałowego, umożliwiając rozwój przedsiębiorczości oraz inwestycje w kapitał ludzki (Shen i in. 2010, s. 198). Wpływ tych transferów na nierówności dochodowe ma potencjalnie inny kierunek w krótkim i długim okresie, ostateczny efekt można zatem określić wyłącznie w sferze empirycznej. Odpowiednie badania zostały przytoczone w drugiej części pracy. 
Koncepcje teoretyczne łączące wzrost nierówności dochodowych z bezpośrednimi inwestycjami zagranicznymi (BIZ) odróżniają przypadek kraju dokonującego inwestycji (ang. home country) od przyjmującego inwestycje (ang. host country). Osobno rozważane są również inwestycje wertykalne, skoncentrowane na optymalizacji kosztów produkcji, oraz horyzontalne, mające na celu rozszerzenie rynków zbytu (Guschanski, Onaran 2018, s. 49). Należy również uwzględnić poziom rozwoju gospodarczego danego kraju. Przykładem teorii czerpiącej zarówno z hipotezy zmiany technologicznej, jak i z twierdzenia Stolpera - Samuelsona może być tzw. model północ - południe (Feenstra, Hanson 1995, s. 2). Zgodnie $\mathrm{z}$ tą teorią za pomocą BIZ kraje rozwinięte (północ) dokonują relokacji produkcji wykorzystującej pracę nisko wykwalifikowaną do krajów rozwijających się (południa). W krajach rozwiniętych, zgodnie z przewidywaniami twierdzenia Stolpera - Samuelsona, następuje wzrost nierówności dochodowych. Nierówności nie zmniejszają się jednak w krajach rozwijających się, ponieważ praca nisko wykwalifikowana z punktu widzenia północy jest pracą stosunkowo wysoko wykwalifikowaną na południu i wzrost popytu na tę kategorię pracy przekłada się na wzrost zróżnicowania płac.

Sugeruje się, że BIZ, prowadząc do relokacji produkcji za granicę , mogą wywierać wpływ na spadek zatrudnienia w kraju inwestora, zwiększając w ten sposób rozwarstwienie dochodów (Perez, Gomes 2015, s. 16). Poza tym przedsiębiorstwa transnarodowe dzięki osiąganym korzyściom skali oraz transferowi technologii ${ }^{4}$ cechują się przeciętnie wyższą produktywnością i są w stanie oferować wyższe płace niż przedsiębiorstwa ograniczone do rynku krajowego, co przekłada się na zwiększenie nierówności zarówno w kraju pochodzenia, jak i przeznaczenie inwestycji (Mihaylova 2015, s. 28). Z drugiej strony wskazuje się na długookresowe efekty dyfuzji wiedzy i technologii zachodzące w obydwu krajach, prowadzące do zniwelowania różnic w produktywności pomiędzy przedsiębiorstwami. Sprzyja to wyrównywaniu poziomu wynagrodzeń między sektorem krajowym i umiędzynarodowionym, zmniejszając tym samym ogólny poziom nierówności dochodowych (Mihalyova 2015, s. 25).

Tematem niniejszego artykułu jest kwestia międzynarodowych transferów dochodów czynników produkcji. Zakres tego zjawiska jest jednak ściśle powiązany ze skalą samych migracji zarobkowych oraz BIZ (Akkermans 2017, s. 12-15). Wynika z tego, że na potrzeby artykułu należy przyjrzeć się nie tylko wspomnianym badaniom bezpośrednio skoncentrowanym na przychodach pierwotnych, lecz również analizom sumarycznego wpływu przepływów czynników produkcji na nierówności dochodowe.

\footnotetext{
${ }^{3}$ Odnosi się to przede wszystkim do BIZ o charakterze wertykalnym, mających na celu obniżenie kosztów produkcji.

${ }^{4}$ Wskazuje się, że transfer technologii oraz know-how następuje zarówno z kraju inwestora do kraju przeznaczenia inwestycji, jak i w przeciwnym kierunku (Perez, Gomes 2015, s. 18).
} 


\section{Globalizacja a nierówności - literatura empiryczna}

Dotychczasowe empiryczne badania zależności pomiędzy emigracją zarobkową a nierównościami dochodowymi uwzględniały transfer dochodów z pracy do kraju pochodzenia migrantów, skupiały się jednak na emigrantach z krajów o niskim poziomie dochodu. V. Koechlin i G. Leon (2007), analizując dane przekrojowe dla 78 krajów rozwijających się, doszli do wniosku, że transfery dochodów do kraju pochodzenia przyczyniają się do wzrostu nierówności dochodowych w krótkim okresie. W długim okresie działają natomiast na rzecz zmniejszenia rozpiętości dochodów (Koechlin, Leon 2007, s. 138). Zbieżnych rezultatów dostarcza dynamiczny strukturalny model migracji ekonomicznych (Shen i in. 2010), który sugeruje U-kształtny profil zmian badanej zależności w czasie (s. 218). Z kolei wyniki modelu opartego na danych panelowych dla 65 krajów rozwijających się i okresu 1970-2015 wskazują, że transfer dochodów do kraju pochodzenia sprzyja wzrostowi nierówności dochodowych tylko w przypadku krajów o słabo rozwiniętym sektorze finansowym (Majeed 2016, s. 274). Istnieją również liczne studia przypadków dla poszczególnych krajów: przy pomocy analizy kointegracji oraz modelu VECM wykazano m.in. dodatnią relację pomiędzy transferami dochodów emigrantów a nierównościami dochodowymi w Pakistanie (Mushtaq i in. 2017, s. 334). Jak już odnotowano, wszystkie te prace koncentrują się na krajach rozwijających się, nie spotkano się natomiast z analizami omawianej zależności dotyczącymi grupy krajów wschodzących.

W literaturze przedmiotu wpływ BIZ na nierówności dochodowe w kraju pochodzenia inwestycji nie cieszył się dotychczas tak dużym zainteresowaniem, jak skutki inwestycji dla kraju przeznaczenia BIZ. C. Choi (2006) zaproponował model oparty na danych panelowych dla 119 krajów i okresu 1993-2002, w którym wśród zmiennych objaśniających poziom nierówności dochodowych znalazły się zasoby BIZ ulokowanych w danym kraju oraz pochodzących z danego kraju wyrażone w stosunku do PKB. Zastosowaną metodą estymacji była klasyczna metoda najmniejszych kwadratów dla danych panelowych (ang. pooled OLS). Oszacowanie parametru przy zmiennej mierzącej wpływ zasobu BIZ pochodzących $\mathrm{z}$ danego kraju jest dodatnie oraz istotne statystycznie niezależnie od specyfikacji modelu (Choi 2006, s. 814). Zastosowana metoda badawcza nie uwzględnia jednak ewentualnej heterogeniczności badanego efektu pomiędzy krajami. Ignoruje również problem możliwej niestacjonarności analizowanych zmiennych, co grozi wystąpieniem regresji pozornych i błędnym oszacowaniem statystyk testowych (Welfe 2018, s. 413).

Rozwiązaniem przedstawionego problemu jest sięgnięcie do narzędzi kointegracji panelowej ${ }^{5}$. S. Celik i U. Basdas (2010) przeanalizowali zależności pomiędzy nierównościami dochodowymi mierzonymi współczynnikiem Giniego a strumieniami

\footnotetext{
${ }^{5} \mathrm{~W}$ przypadku większości krajów nie ma wystarczająco licznych prób, które umożliwiłyby przeprowadzenie analizy na podstawie pojedynczych szeregów czasowych.
} 
napływu oraz wypływu BIZ wyrażonymi jako procent PKB dla trzech grup krajów: rozwiniętych, rozwijających się oraz azjatyckich krajów „cudu gospodarczego". W próbie znalazło się łącznie 13 krajów, dane obejmowały okres 1990-2005. Testy pierwiastka jednostkowego oraz kointegracji pozwoliły na zastosowanie estymatora FMOLS (ang. fully modified ordinary least squares). Oszacowanie parametru kwantyfikującego zależność pomiędzy nierównościami dochodowymi a strumieniami wypływu BIZ jest ujemne i statystycznie istotne (Celik, Basdas 2010, s. 368). Oznacza to, że w badanej grupie krajów ${ }^{6}$ wzrost wypływu BIZ wiązał się ze zmniejszeniem nierówności dochodowych.

Zbliżone podejście metodologiczne zastosowali D. Herzer i P. Nunnenkamp (2013), badając zależność między nierównościami dochodowymi a zasobami BIZ dla 8 europejskich krajów rozwiniętych w okresie 1980-2000. Po przeprowadzeniu testów pierwiastka jednostkowego oraz kointegracji oszacowano parametry postulowanej zależności przy pomocy estymatora DOLS. Długookresowa zależność pomiędzy zmiennymi jest ujemna i statystycznie istotna. Wyniki tej analizy potwierdzono, oszacowując parametry wektorowego modelu korekty błędem. Jednocześnie stwierdzono, że w krótkim okresie badana zależność jest dodatnia i statystycznie istotna (Herzer, Nunnenkamp 2013, s. 409). Długookresowy związek pomiędzy zmiennymi jest ponadto obustronny: zmiany nierówności dochodowych są przyczyną zmian zasobów BIZ pochodzących z danego kraju, a zmiany zasobów BIZ pociągają za sobą ewolucję nierówności dochodowych. Podsumowując - w długim okresie wzrost zasobów BIZ pochodzących z danego kraju jest związany ze spadkiem nierówności dochodowych. Eksport kapitału prowadzi do wzrostu nierówności dochodowych w kraju pochodzenia jedynie w krótkim okresie.

Inną metodę badawczą zaproponowali W. Deng i Y. Lin (2012) w swojej analizie zależności pomiędzy nierównościami dochodowymi a strumieniami i zasobami BIZ dla 109 krajów w okresie 1970-2007. Wykorzystanie metod regresji semiparametrycznej umożliwiło uwzględnienie heterogeniczności parametrów w zależności od poziomu rozwoju kraju oraz zasobu kapitału ludzkiego. Wykazano, że skala zależności pomiędzy BIZ a nierównościami dochodowymi zależy nieliniowo od zasobu kapitału ludzkiego w danym kraju. Wypływ BIZ nie oddziałuje istotnie na nierówności dochodowe w krajach o wysokim oraz niskim poziomie rozwoju. Wzrost strumieni i zasobów BIZ pochodzących z danego kraju wiąże się natomiast ze wzrostem nierówności dochodowych w krajach o średnim poziomie rozwoju i niskim zasobie kapitału ludzkiego (Deng, Lin 2012, s. 869). Wydaje się, że ta charakterystyka może się odnosić do wielu krajów wschodzących.

Przywołane prace nie pozwalają na pozytywną weryfikację empiryczną hipotezy o związku pomiędzy BIZ a wzrostem nierówności dochodowych w kraju pochodzenia. Jak już jednak odnotowano, oddziaływanie BIZ na nierówności do-

\footnotetext{
${ }^{6}$ Wpływ strumieni BIZ na kraj inwestora przeanalizowano tylko dla trzech krajów rozwiniętych. Niewielki rozmiar próby każe zatem traktować te wyniki z ostrożnością.
} 
chodowe w kraju inwestora jest wielopłaszczyznowe. Brak czytelnego związku pomiędzy strumieniami lub zasobami BIZ a rosnącym zróżnicowaniem dochodów w kraju inwestora nie oznacza, że omawiana zależność nie dotyczy transferu dochodów inwestycyjnych. Rozstrzygnięcie tej kwestii oraz określenie roli, jaką odgrywają transfery dochodów emigrantów w krajach wschodzących, są przedmiotem osobnej analizy empirycznej w części trzeciej artykułu.

\section{Przychody pierwotne a nierówności - model kointegracji panelowej}

W celu zbadania zależności pomiędzy przychodami pierwotnymi a nierównościami dochodowymi postanowiono zastosować narzędzia kointegracji panelowej. Dane dotyczące przychodów pierwotnych zaczerpnięto z bazy danych Banku Światowego (https://databank.worldbank.org/data) i wyrażono w stosunku do PKB danego kraju? Z Za wskaźnik nierówności dochodowych zdecydowano się przyjąć udział najwyższego centyla rozkładu w dochodzie narodowym ${ }^{8}$, zaczerpnięty z bazy danych World Inequality Database (https://wid.world/data). Przyczyn wyboru takiego wskaźnika nierówności dochodowych zamiast któregoś z powszechnie stosowanych mierników syntetycznych (takich jak współczynnik Giniego) jest kilka. Po pierwsze, udział najwyższego centyla w dochodzie narodowym publikowany w bazie WID jest obliczany na podstawie informacji pochodzących z różnych źródeł: badań ankietowych, statystyki publicznej oraz źródeł fiskalnych. Uważa się, że umożliwia to dokładniejsze oszacowanie nierówności dochodowych niż opieranie się wyłącznie na konwencjonalnych źródłach ankietowych (Brzeziński 2017, s. 2). Po drugie, zmiany udziału najwyższych kwantyli w dochodzie narodowym dobrze korelują z innymi wskaźnikami nierówności dochodowych i mogą być stosowane zamiennie (Leigh 2007, s. 589-603). Po trzecie, wskaźniki tego typu są coraz powszechniej stosowane zarówno w pracach empirycznych (por. Chintrakarn i in. 2012, s. 791), jak i teoretycznych (World Inequality Report 2018, s. 27).

Założeniem niniejszej pracy było zbadanie omawianej zależności w krajach spełniających przyjętą definicję rynków wschodzących. Dobór krajów i okresu analizy był wynikiem kompromisu pomiędzy dążeniem z jednej strony do zachowania elementarnej porównywalności, z drugiej zaś do osiągnięcia maksymalnego rozmiaru próby przy ograniczonej dostępności danych. Uznano, że spójność metodologiczna wykorzystywanych danych ma większe znaczenie dla celów prowadzonej analizy niż podobieństwo strukturalne wybranych krajów. Ostatecznie otrzymano zrównoważony panel złożony z sześciu krajów (Czechy,

\footnotetext{
${ }^{7} \mathrm{~W}$ dalszej części pracy przychody pierwotne jako procent PKB oznaczono jako PIR (z ang. primary income receipts).

${ }^{8} \mathrm{~W}$ dalszej części pracy: TOP1.
} 
Egipt, Polska, Rosja, Turcja, Chile) dla okresu 1994-2014, co daje łącznie 126 obserwacji ${ }^{9}$. Podstawowe statystyki opisowe dla udziału najwyższego centyla w dochodzie narodowym (zmienna TOP1) oraz przychodów pierwotnych (zmienna $P I R)$ przedstawiono w tabeli 1 .

Przyjęto hipotezę, że pomiędzy badanymi zmiennymi występuje stabilna, długookresowa zależność:

$\mathrm{TOP} 1_{\mathrm{it}}=\alpha_{01}+\alpha_{1 \mathrm{i}} \cdot \mathrm{PIR}_{\mathrm{it}}+\varepsilon_{\mathrm{it}}$

Tabela 1. Statystyka opisowa

\begin{tabular}{|l|c|c|c|c|}
\cline { 2 - 5 } \multicolumn{1}{c|}{} & \multicolumn{2}{c|}{ Średnia (\%) } & \multicolumn{2}{c|}{ Współczynnik zmienności (\%) } \\
\cline { 2 - 5 } \multicolumn{1}{c|}{} & TOP1 & PIR & TOP1 & PIR \\
\hline Czechy & 8,84 & 3,07 & 10,67 & 26,88 \\
\hline Egipt & 18,35 & 1,44 & 6,45 & 71,14 \\
\hline Polska & 11,53 & 2,04 & 9,99 & 44,50 \\
\hline Rosja & 20,63 & 2,10 & 20,59 & 36,05 \\
\hline Turcja & 21,88 & 0,85 & 16,24 & 24,98 \\
\hline Chile & 22,12 & 2,22 & 7,38 & 38,26 \\
\hline
\end{tabular}

Źródło: opracowanie własne na podstawie https://wid.world/data i https://databank.worldbank.org/ data; obliczenia w pakiecie statystycznym R.

W równaniu [1] subskrypt $t$ oznacza kolejne lata, a subskrypt $i$ poszczególne kraje podlegające analizie. Założono, że poszczególne kraje odznaczają się niezmiennymi w czasie efektami strukturalnymi (parametr $\alpha_{0 i}$ ) oraz że siła i kierunek analizowanej zależności mogą $\alpha_{1 \mathrm{i}}$ być $\mathrm{w}$ ogólnym przypadku zależne od kraju (subskrypty indywidualne parametru przy zmiennej PIR). Jedyną zmienną objaśniającą $\mathrm{w}$ równaniu [1] są przychody pierwotne. Jest to uzasadnione, ponieważ w przypadku występowania kointegracji pomiędzy zmiennymi składnik losowy regresji jest stacjonarny (Chintrakarn $\mathrm{i}$ in. 2012, s. 791) i żadna istotna zmienna wchodząca w skład relacji kointegrującej nie mogła zostać pominięta. Oznacza to, że estymatory modeli kointegracyjnych zastosowane w niniejszej analizie są odporne na problem pominiętych zmiennych (Herzer, Nunnenkamp 2013, s. 401).

Aby mogła zaistnieć relacja kointegrująca, zmienne muszą być zintegrowane $\mathrm{w}$ tym samym stopniu. Postawiono hipotezę, że udział najwyższego centyla w dochodzie narodowym oraz przychody pierwotne są zintegrowane w stopniu pierwszym. Aby zweryfikować tę hipotezę przeprowadzono panelowe testy pierwiastka jednostkowego dla poziomów oraz pierwszych przyrostów obu zmiennych.

\footnotetext{
${ }^{9}$ Przy niewielkiej liczbie szacowanych parametrów jest to rozmiar próby wystarczający do zastosowania wybranych narzędzi statystycznych (por. Herzer, Nunnenkamp 2013).
} 
Tabela 2. Panelowe testy pierwiastka jednostkowego

\begin{tabular}{|l|c|c|c|c|}
\hline Test & TOP $_{\text {it }}$ & PIR $_{\text {it }}$ & $\Delta \mathrm{TOP}_{\text {it }}$ & $\Delta$ PIR $_{\text {it }}$ \\
\hline \multicolumn{5}{|c|}{ Empiryczny poziom istotności (p-value) } \\
\hline Levin-Lin-Chu & 0,0035 & 0,0029 & 0,0000 & 0,0000 \\
\hline Im-Pesaran-Shin & 0,0411 & 0,1289 & 0,0000 & 0,0000 \\
\hline Maddala-Wu & 0,0806 & 0,2199 & 0,0000 & 0,0000 \\
\hline Hadri & 0,0000 & 0,0000 & 0,4240 & 0,8038 \\
\hline \multicolumn{5}{|c|}{ Statystyka CIPS } \\
\hline CIPS & $-1,9817$ & $-1,7865$ & $-4,4786$ & $-3,8793$ \\
\hline
\end{tabular}

Uwagi: w specyfikacji regresji testowej uwzględniono wyrazy wolne. Nie uwzględniono trendów deterministycznych.

Źródło: opracowanie własne na podstawie https://wid.world/data i https://databank.worldbank.org/ data; obliczenia w pakiecie statystycznym R.

Zastosowano testy pierwszej generacji Im-Pesarana-Shina (IPS), Levina-Lin-Chu (LLC), Maddali-Wu (MW) i Hadriego oraz test drugiej generacji (CIPS) M. Pesarana (por. Baltagi 2005, s. 239-251) (wyniki przedstawia tabela 2). Rezultaty testów są niejednoznaczne, jednak ze względu na niewielki wymiar czasowy panelu i możliwość występowania korelacji przestrzennych najbardziej wiarygodnych wyników dostarczają testy MW oraz CIPS (Konopczak, Welfe 2014, s. 469), które potwierdzają hipotezę o zintegrowaniu obu zmiennych w stopniu pierwszym.

W kolejnym kroku przystąpiono do testowania hipotezy o skointegrowaniu analizowanych zmiennych. W tym celu zastosowano panelowy test kointegracji Pedroniego oparty na procedurze Engle'a - Grangera (Barbieri 2008, s. 12-16). W panelach o krótkim wymiarze czasowym testy tego typu odznaczają się mniejszym zniekształceniem rozmiaru niż alternatywne testy oparte na metodzie Johansena (Konopczak, Welfe 2014, s. 472). Wyniki testu zamieszczono w tabeli 3.

Tabela 3. Panelowy test kointegracji Pedroniego $\left(\mathrm{H}_{0}\right.$ : brak kointegracji)

\begin{tabular}{|l|c|c|}
\hline Statystyka & Wartość empiryczna & P-value \\
\hline$v$-panelowa & $-3,0415$ & 0,0012 \\
\hline$\rho$-panelowa & $-7,4002$ & 0,0000 \\
\hline t-panelowa (nieparametryczna) & $-10,752$ & 0,0000 \\
\hline t-panelowa (parametryczna) & $-2,4 \mathrm{e} 18$ & 0,0000 \\
\hline$\rho$-grupowa & $-0,4887$ & 0,3125 \\
\hline t-grupowa (nieparametryczna) & $-2,9280$ & 0,0017 \\
\hline t-grupowa (parametryczna) & $-3,0417$ & 0,0018 \\
\hline
\end{tabular}

Uwagi: w specyfikacji regresji testowej uwzględniono wyrazy wolne. Nie uwzględniono trendów deterministycznych.

Źródło: opracowanie własne na podstawie https://wid.world/data i https://databank.worldbank.org/ data; obliczenia w pakiecie statystycznym R. 
W przypadku małych paneli największą mocą i najmniejszym zniekształceniem rozmiaru testu cechują się statystyki t-grupowe. Obliczone wartości empiryczne tych statystyk pozwalają na odrzucenie hipotezy o braku kointegracji na rzecz hipotezy alternatywnej o skointegrowaniu zmiennych na każdym typowym poziomie istotności. Uzyskane rezultaty pozwalają przejść do szacowania parametrów relacji długookresowej pomiędzy przychodami pierwotnymi a nierównościami dochodowymi.

W charakterze podstawowej metody estymacji postanowiono zastosować estymator CCE (ang. common correlated effects) zaproponowany przez Pesarana (2006). Oszacowano parametry równania:

$\mathrm{TOP} 1_{\mathrm{it}}=\alpha_{01}+\alpha_{1 \mathrm{i}} \cdot \mathrm{PIR}_{\mathrm{it}}+\alpha_{2} \cdot \overline{\mathrm{PIR}}_{\mathrm{t}}+\alpha_{3} \cdot \overline{\mathrm{TOP}}_{\mathrm{t}}+\varepsilon_{\mathrm{it}}$

gdzie:

$\overline{\mathrm{PIR}}_{\mathrm{t}}-\frac{1}{6} \sum_{\mathrm{i}} \mathrm{PIR}_{\mathrm{it}}-$ średni udział przychodów pierwotnych w PKB dla wszystkich badanych krajów w roku $t$;

$\overline{\mathrm{TOP}}_{\mathrm{t}}=\frac{1}{6} \sum_{\mathrm{i}} \mathrm{TOP} 1_{\mathrm{it}}-$ analogicznie, średni udział najwyższego centyla w dochodzie narodowym w roku $t$.

Założono, że siła i kierunek relacji pomiędzy skointegrowanymi zmiennymi są takie same we wszystkich analizowanych krajach. Z powodu różnic strukturalnych nieuchronnie występujących pomiędzy krajami stanowi to pewne uproszczenie. Podnosi się jednak, że korzyści płynące ze zwiększonej efektywności takiego zdefiniowania estymatora przeważają nad kosztami w postaci ewentualnej niezgodności punktowych oszacowań parametrów (Herzer, Nunnenkamp 2013, s. 402). Wyniki estymacji parametrów równania [2] zamieszczono w tabeli 4.

Tabela 4. Oszacowania parametrów modeli CCE/DOLS

\begin{tabular}{|c|c|c|c|c|}
\hline Równanie & Metoda & $\alpha_{1}$ & P-value & $\mathrm{R}^{2}$ \\
\hline$[2]$ & CCE (FE) & 1,8849 & 0,0000 & 0,2170 \\
\hline$[3]$ & DOLS (FE) & 1,6539 & 0,0000 & 0,2109 \\
\hline$[3]$ & DOLS (FGLS) & 1,7456 & 0,0000 & 0,9036 \\
\hline
\end{tabular}

Uwagi: w nawiasach zaznaczono metodę estymacji. FE - estymator efektów stałych (ang. fixed effects), FGLS - uogólniona metoda najmniejszych kwadratów (ang. feasible generalised least squares).

Źródło: opracowanie własne na podstawie https://wid.world/data i https://databank.worldbank.org/ data; obliczenia w pakiecie statystycznym R.

Aby zweryfikować uzyskane wyniki, analizowaną zależność oszacowano dodatkowo za pomocą estymatora DOLS (ang. dynamic ordinary least squares). Można go stosować w panelach o krótkim wymiarze czasowym, jest również 
odporny na problem pominiętej zmiennej (Herzer, Nunnenkamp 2013, s. 407). W porównaniu ze stosowanym powszechnie estymatorem FMOLS charakteryzuje się także mniejszym obciążeniem w małych próbach (Konopczak, Welfe 2014, s. 475), jest zatem bardziej adekwatny do niniejszej analizy. Szacowano parametry następującego modelu:

$\mathrm{TOP} 1_{\mathrm{it}}=\alpha_{01}+\alpha_{1} \cdot \mathrm{PIR}_{\mathrm{it}}+\sum_{\mathrm{j}}^{1}={ }_{-1} \varphi_{\mathrm{j}} \cdot \Delta \mathrm{PIR}_{\mathrm{it}-\mathrm{j}}+\varepsilon_{\mathrm{it}}$

gdzie $\Delta \mathrm{PIR}_{\mathrm{it}-\mathrm{j}}$ oznacza opóźnienia oraz wyprzedzenia pierwszych przyrostów zmiennej PIR odpowiednio dla dodatnich i ujemnych wartości subskryptu $j^{10}$.

Zastosowanie wartości opóźnionych oraz wyprzedzonych pozwala uwzględnić problem ewentualnej endogeniczności oraz seryjnej korelacji, prowadząc do uzyskania nieobciążonych oszacowań parametrów (Herzer, Nunnenkamp 2013, s. 408). Parametry szacowano zarówno przy użyciu estymatora efektów stałych, jak i uogólnionej metody najmniejszych kwadratów. Wyniki estymacji parametrów równania [3] przedstawiono w tabeli 5.

Niezależnie od zastosowanej metody estymacji oszacowania parametru $\alpha_{1}$ są dodatnie oraz statystycznie istotne. Cechują się ponadto zbliżonym rzędem wielkości, wahając się od 1,65 dla estymatora DOLS szacowanego przy uwzględnieniu efektów stałych do 1,88 w przypadku estymatora CCE. Oznacza to, że wzrost udziału przychodów pierwotnych w PKB o $1 \mathrm{pp}$. wiąże się przeciętnie ze wzrostem udziału najwyższego centyla w dochodzie narodowym wyraźnie większym niż 1 pp.

Skoro badane zmienne są skointegrowane, to na mocy twierdzenia Grangera o reprezentacji w układzie występuje mechanizm korekty błędem (Welfe 2018, s. 410). Zdecydowano się zatem oszacować parametry wektorowego modelu korekty błędem (VECM). Umożliwi to nie tylko dalsze potwierdzenie dotychczasowych rezultatów, ale również zbadanie relacji przyczynowych zachodzących pomiędzy zmiennymi. Dokonano estymacji parametrów następującego modelu VECM:

$\Delta T O P 1_{i t}=\alpha_{0 i}+\alpha_{1} \cdot \Delta T O P 1_{i t-1}+\alpha_{2} \cdot \Delta P I R_{i t-1}+\gamma \cdot \overline{E C T}_{i t-1}+\varepsilon_{i t}(4)$

$\Delta P I R_{i t}=\beta_{0 i}+\beta_{1} \cdot \Delta T O P 1_{i t-1}+\beta_{2} \cdot \Delta P I R_{i t-1}+\theta \cdot \overline{E C T}_{i t-1}+\vartheta_{i t}$

Jako $\widehat{\mathrm{ECT}}_{\mathrm{it}} \mathrm{w}$ równaniach (4) oraz (5) oznaczono czynnik korekty błędem obliczony na podstawie wartości teoretycznych zmiennej TOP1 otrzymanych przy użyciu estymatora DOLS.

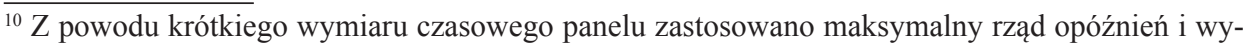
przedzeń równy 2 . 
Oznacza to, że:

$\widehat{E C T}_{i t}=T O P 1_{i t}-\hat{\alpha}_{1}^{D O L S} \cdot P I R_{i t}$

Wyniki oszacowań parametrów modelu VECM znajdują się w tabeli 5.

Tabela 5. Oszacowania parametrów modelu VECM

\begin{tabular}{|l|c|c|}
\hline \multicolumn{1}{|c|}{ Zmienna } & Oszacowanie parametru & P-value \\
\hline \multicolumn{2}{|c|}{ Zmienna zależna: $\Delta \mathrm{TOP}_{1}{ }_{\mathrm{it}}$} \\
\hline$\Delta \mathrm{TOP}_{\mathrm{it}-1}$ & $-0,0087$ & 0,9285 \\
\hline$\Delta \mathrm{PIR}_{\mathrm{it}-1}$ & 0,0754 & 0,8025 \\
\hline$\widehat{\mathrm{ECT}}_{\mathrm{it}-1}$ & $-0,2742$ & 0,0000 \\
\hline \multicolumn{2}{|c|}{${\text { Zmienna zależna: } \Delta \mathrm{PIR}_{\mathrm{it}}}$} \\
\hline$\Delta \mathrm{TOP}_{\mathrm{it}-1}$ & $-0,0217$ & 0,5110 \\
\hline$\Delta \mathrm{PIR}_{\mathrm{it}-1}$ & 0,1205 & 0,2406 \\
\hline$\widehat{\mathrm{ECT}}_{\mathrm{it}-1}$ & 0,0189 & 0,3635 \\
\hline
\end{tabular}

Źródło: opracowanie własne na podstawie https://wid.world/data i https://databank.worldbank.org/ data; obliczenia w pakiecie statystycznym $\mathrm{R}$.

Otrzymane rezultaty wskazują, że parametr $\gamma$ jest istotnie mniejszy od zera. Wszystkie pozostałe parametry w układzie są statystycznie nieistotne. Pozwala to stwierdzić, że przychody pierwotne są długookresową przyczyną zmian nierówności dochodowych. Opisywana przyczynowość nie zachodzi jednak w przeciwnym kierunku, nie występują również zależności o charakterze krótkookresowym. Innymi słowy, udział przychodów pierwotnych w PKB jest słabo egzogeniczny względem udziału najwyższego centyla w dochodzie narodowym. Wnioski z analizy modelu VECM należy jednak traktować w tym przypadku z pewną dozą ostrożności z uwagi na niewielki wymiar czasowy panelu.

Podsumowując rezultaty przeprowadzonej analizy empirycznej, należy zauważyć, że panelowe testy pierwiastka jednostkowego oraz panelowy test kointegracji wykazały zintegrowanie w stopniu pierwszym oraz skointegrowanie badanych zmiennych. Oszacowane parametry zależności długookresowej wskazują, że wzrost przychodów pierwotnych w stosunku do PKB jest powiązany ze wzrostem nierówności dochodowych. Znak, rząd wielkości oraz istotność statystyczna oszacowań są niezależne od zastosowanego estymatora. Udowodniono również istnienie długookresowej relacji przyczynowej przebiegającej w kierunku od przychodów pierwotnych do nierówności dochodowych. 


\section{Podsumowanie}

Powszechna tendencja wzrostowa nierówności dochodowych, która zarysowała się w kilku ostatnich dekadach, przyczyniła się do rozwoju badań nad zmianami w rozkładzie dochodów ludności. Wśród potencjalnych przyczyn omawianego zjawiska, obok czynników technologicznych oraz instytucjonalnych, wskazuje się na procesy globalizacyjne, do których należy zaliczyć rosnącą wymianę handlową, migracje zarobkowe oraz inwestycje zagraniczne.

Dotychczasowe badania wpływu globalizacji na nierówności dochodowe skupiały się na roli przepływów towarów, osób i kapitału, nie akcentując znaczenia transferu dochodów generowanych przez te skumulowane przepływy. W niniejszej pracy przeanalizowano zależność pomiędzy nierównościami dochodowymi a kategorią dochodów rejestrowaną na rachunku obrotów bieżących jako dochody pierwotne. Zdecydowano się skoncentrować na zbadaniu oddziaływania tych przepływów na kraj przeznaczenia transferów, dlatego w analizie wykorzystano przychody pierwotne zamiast dochodów pierwotnych netto. Jednocześnie ograniczono analizę do krajów wschodzących, na temat których literatura wypowiadała się dotąd szczególnie oszczędnie. Ze względu na relatywnie krótki zakres czasowy dostępnych danych postanowiono wykorzystać narzędzia dynamicznej analizy panelowej.

Przeprowadzona analiza wykazała, po pierwsze, że w badanym przypadku dopuszczalne jest zastosowanie metod kointegracji panelowej. Po drugie, pomiędzy udziałem przychodów pierwotnych w PKB a udziałem najwyższego centyla w dochodzie narodowym zachodzi długookresowa, dodatnia zależność o wysokiej istotności statystycznej. Wyższy poziom przychodów pierwotnych w stosunku do PKB systematycznie wiązał się zatem z wyższym poziomem nierówności dochodowych. Po trzecie, relacja przyczynowa między zmiennymi przebiega w kierunku od przychodów pierwotnych do nierówności dochodowych i zachodzi wyłącznie w długim okresie. Uzyskane wyniki są odporne na alternatywne metody estymacji.

Rezultaty otrzymane w niniejszej pracy wymagają komentarza w kontekście omówionej empirycznej literatury przedmiotu. Przychody pierwotne są konsekwencją zjawisk emigracji oraz inwestycji zagranicznych. Rola emigracji w kształtowaniu nierówności dochodowych w krajach wschodzących nie została dotychczas jednoznacznie wyjaśniona ${ }^{11}$. Przytoczone badania dotyczące związku pomiędzy BIZ a nierównościami dochodowymi w kraju inwestora zdają się prowadzić do przeciwnych wniosków niż analiza będąca przedmiotem niniejszego opracowania, sugerując ujemny charakter tej zależności. Należy jednak pamiętać, że omówione badania empiryczne skupiały się na krajach wysoko rozwiniętych, a badane zjawisko może przebiegać inaczej w krajach na różnym poziomie rozwoju. Sugerują to zresztą jedyne przytoczone wyniki dotyczące krajów średnio

\footnotetext{
${ }^{11}$ Należy zauważyć, że na tle pozostałych danych demograficznych jakość danych na temat migracji jest stosunkowo niska, co utrudnia analizowanie krótkookresowych skutków tego zjawiska.
} 
rozwiniętych (Deng, Lin 2012). Poza tym oddziaływanie BIZ na rozkład dochodów ludności jest wielopłaszczyznowe i można przypuszczać, że niekorzystne skutki dystrybucyjne transferu dochodów pierwotnych są przynajmniej częściowo równoważone innymi opisanymi mechanizmami ekonomicznymi.

Najpoważniejszym ograniczeniem dla niniejszej analizy była niezadowalająca dostępność wysokiej jakości danych statystycznych. Pojawienie się nowych danych pozwoliłoby na rozszerzenie analizy na większą liczbę krajów wschodzących oraz na zastosowanie innego poziomu agregacji zmiennych. Na obecnym etapie przedstawiony obraz zależności pomiędzy transferami dochodów generowanych przez procesy globalizacyjne a nierównościami dochodowymi w krajach średnio rozwiniętych ma z konieczności charakter cząstkowy.

\section{Bibliografia}

Acemoglu D., Autor D. (2010), Skills, tasks and technologies: Implications for employment and earnings, ,NBER Working Paper Series”, nr 16082, s. 154. Akkermans D. (2017), Net profit flow per country from 1980 to 2009: The longterm effects of foreign direct investment, „PLoS ONE, 12 (6), https://doi. org/10.1371/journal.pone.0179244 (data dostępu: 19 marca 2019).

Baltagi B. (2005), Econometric analysis of panel data, John Wiley \& Sons, Chichester, s. 237-265.

Barbieri L. (2008), Panel cointegration tests: A survey, „Rivista Internazionale di Scienze Sociali", t. 116, nr 1, s. 3-36.

Brzeziński M. (2017), Nierówności dochodowe i majątkowe w Europie - fakty, przyczyny, konsekwencje [w:] J. Kleer, K. Prandecki (red.), Zróżnicowanie dochodowe i spoleczne Europy, PAN, Warszawa, 2017, s. 10.

Budnikowski A. (2014), Ekonomia międzynarodowa, PWE, Warszawa, s. 93-100. Card D. (2009), Immigration and inequality, „American Economic Review: Papers and Proceedings", 99 (2), s. 1-21.

Celik S., Basdas U. (2010), How does globalization affect income inequality? A panel data analysis, „International Advances in Economic Research”, t. 16, nr 4, s. 358-370.

Chintrakarn P. i in. (2012), FDI and income inequality: Evidence from a panel of U.S. states, „Economic Inquiry”, t. 50, nr 3, s. 788-801.

Choi C. (2006), Does foreign direct investment affect domestic income inequality?, „Applied Economics Letters”, t. 12, nr 12, s. 811-814.

Deng W., Lin Y. (2013), Parameter heterogeneity in the foreign direct investment - income inequality relationship: A semiparametric regression analysis, „Empirical Economics”, t. 45, nr 2, s. 845-872.

Feenstra R., Hanson G. (1995), Foreign investment, outsourcing and relative wages, „NBER Working Papers Series”, nr 5121, s. 53. 
Guschanski A., Onaran Ö. (2018), Determinants of the wage share: A cross-country comparison using sectoral data, „CESifo Forum. Ifo Institut - LeibnizInstitut für Wirtschaftsforschung an der Universität München”, t. 19, nr 2, s. 44-54.

Herzer D. i in. (2014), FDI and income inequality - evidence from Latin American economies, „Review of Development Economics”, 18(4), s. 778-793.

Herzer D., Nunnenkamp P. (2013), Inward and outward FDI and income inequality: Evidence from Europe, Review of World Economics, t. 149, s. 395-422.

Kierzenkowski R., Koske I. (2013), The drivers of labor income inequality - A literature review, „Journal of International Commerce, Economics and Policy", t. 4, nr 1, s. 32.

Koechlin V., Leon G. (2007), International remittances and income inequality: An empirical investigation, „Journal of Economic Policy Reform”, t. 10, $\mathrm{nr} 2$, s. $123-141$.

Konopczak K., Welfe A. (2014), Efekt Balassy-Samuelsona i mechanizmy jego absorpcji, „Ekonomista”, nr 4, s. 463-489.

Leigh A. (2007), How closely do top income shares track other measures of inequality?, „The Economic Journal”, nr 117, s. 589-603.

Majeed T. (2016), Distributional consequences of remittances: Evidence from sixty-five developing countries, „Pakistan Journal of Commerce and Social Sciences", t. 10 (2), s. 274-295.

MFW (2014), Balance of payments and international investment position compilation guide, MFW, Waszyngton, s. 620.

Mihaylova S. (2015), Foreign direct investment and income inequality in Central and Eastern Europe, „Theoretical and Applied Economics”, t. XXII, nr 2 (603), s. 23-42.

Mushtaq M. i in. (2017), Distributional impact of foreign remittances in Pakistan, „Pakistan Business Review”, July 2017, s. 320-338.

Nakonieczna-Kisiel H. (2016), Foreign direct investment and the balance of payments in Poland, Trends in the World Economy, t. 8, s. 111-123.

Perez R.P., Gomes C.N. (2015), Determinants and home country effects of FDI outflows. Evidence from Latin American countries, „ECLAC Studies and Perspectives Series", nr 166, Mexico, s. 71.

Pesaran M. (2006), Estimation and inference in large heterogenous panels with a multifactor error structutre, „Econometrica”, nr 74, s. 967-1012.

Shen I. i in. (2010), Remittances and inequality: A dynamic migration model, „Journal of Economic Inequalities”, t. 8, s. 197-220.

Welfe A. (2018), Ekonometria, PWE, Warszawa, s. 486.

World Development Indicators, https://databank.worldbank.org/data (data dostępu: 19 marca 2019).

World Inequality Database, https://wid.world/data (data dostępu: 19 marca 2019).

World Inequality Report (2018), F. Alvaredo i in. (red.), World Inequality Lab, s. 300. 


\section{Streszczenie}

Do potencjalnych przyczyn wzrostu nierówności dochodowych zalicza się procesy globalizacyjne, w tym migracje ekonomiczne i BIZ. Dotychczasowe badania koncentrowały się na związku między nierównościami dochodowymi a przepływami osób i kapitału. Niewiele uwagi poświęcano generowanym przez nie transferom dochodów rejestrowanym na rachunku obrotów bieżących jako dochody pierwotne. Dotychczasowe analizy poświęcone tym zagadnieniom skupiają się na skutkach transferów dochodów migrantów do kraju pochodzenia i odnoszą się głównie do krajów słabo rozwiniętych. W niniejszej pracy przeanalizowano zależność między przychodami pierwotnymi a nierównościami dochodowymi za pomocą narzędzi kointegracji panelowej dla sześciu krajów wschodzących: Polski, Czech, Egiptu, Rosji, Turcji i Chile. W odróżnieniu od większości dotychczasowej literatury za miernik nierówności dochodowych przyjęto udział najwyższego centyla w dochodzie narodowym wyznaczony na podstawie danych fiskalnych (baza danych WID).

Wyniki analizy wskazują na długookresową, dodatnią zależność pomiędzy udziałem przychodów pierwotnych w PKB a udziałem najwyższego centyla w dochodzie narodowym. Wzrost (spadek) udziału przychodów pierwotnych w PKB stanowi ponadto długookresową przyczynę wzrostu (spadku) nierówności dochodowych. Otrzymane wyniki są odporne na zmianę metody estymacji (CCE, DOLS, VECM). Ograniczeniem niniejszej pracy jest niezadowalająca dostępność porównywalnych danych na temat badanych kategorii, utrudniająca rozszerzenie analizy na większą liczbę krajów wschodzących.

Słowa kluczowe: nierówności dochodowe, bilans płatniczy, kraje wschodzące, kointegracja panelowa.

\section{Summary}

\section{Primary income receipts and income inequality in emerging countries}

The rise in income inequality is often ascribed to globalisation and its various components, such as economic migrations and foreign direct investment. Previous research in this area focused on the relationship between income inequality and flows or stocks of migrants and capital. Little attention has been paid to income flows generated by these categories that are recorded in the balance of payments as primary income. Existing analysis explored the impact of migrants' remittances on the distribution of income in developing countries. This article analyses the relationship between primary income receipts and income inequality using panel cointegration methods for a group of six emerging countries: Poland, the Czech 
Republic, Egypt, Russia, Turkey and Chile. In contrast to the existing literature, income inequality is measured by top percentile income share derived from fiscal data (World Inequalities Database).

The results reveal a long run, positive relationship between primary income receipts as a share of GDP and top percentile income share. There is also a long-run causal relationship between a rise (fall) in primary income receipts and a rise (fall) in income inequality. The results are robust to alternative estimation methods (CCE, DOLS, VECM). The scope of this work is narrowed by the limited availability of comparable data for other emerging countries.

Keywords: income inequality, balance of payments, emerging markets, panel cointegration

JEL: D31, F61, F21, F24 